\title{
Decayed Wood Affecting the Attraction of the Pest Arboretum Termite Nasutitermes corniger (Isoptera: Termitidae) to Resource Foods
}

by

\author{
Vinícius Gazal ${ }^{1,2}$, Omar Bailez², Ana Maria Viana-Bailez², \\ Elen De Lima Aguiar-Menezes ${ }^{1} \&$ Eurípedes Barsanulfo Menezes ${ }^{1}$
}

\section{ABSTRACT}

Nasutitermes corniger shows preferential feeding for the wood of different tree species, but it is not known whether attractiveness is a function of the state of decay. This study examined the foraging behavior of $N$. corniger towards wood in different stages of decay. Wood was exposed to weather for durations of $0,3,6$ or 9 months. Then the wood was placed in a standard foraging arena with termites. Exploration and recruitment behavior were recorded for $1 \mathrm{~h}$. Separate bioassays were conducted for three species: Pinus elliottii, Eucalyptus grandis and Manilkara huberi. In the tests with P. elliottii and $E$. grandis, more individuals were recruited to wood decayed for 6 months (191 and 185, respectively) than to undecayed wood (12 and 69, respectively). Similarly, more individuals were recruited to decayed $M$. huberi wood than undecayed, but only after 9 months ( 249 and 7 , respectively). Decayed wood has therefore been demonstrated to be more attractive to $N$. corniger than undecayed wood. The different decomposition rates necessary to increase attractiveness may be explained by differences in wood density.

Key words: decaying wood, foraging behavior, Nasutitermes, recruitment, termites, wood-decomposition.

\section{INTRODUCTION}

The termite Nasutitermes corniger (Motschulsky) is one of the most harmful arboreal species in Brazil, where it causes damage to wood on buildings and

\footnotetext{
${ }^{1}$ Universidade Federal Rural do Rio de Janeiro-UFRRJ-vgazal@uenf.br

Departamento de Entomologia e Fitopatologia, Rod. Antiga Rio-São Paulo Km 47-Seropédica, Rio de Janeiro-Brazil

${ }^{2}$ Universidade Estadual do Norte Fluminense Darcy Ribeiro-UENF, Laboratório de Entomologia e Fitopatologia, Setor de Semioquímicos, Av. Alberto Lamego 2000 - Parque California 28013602 Campos dos Goytacazes, Rio de Janeiro-Brazil
} 
indoor structures. Control is difficult owing to the construction of polycalic nests, which are often some distance from the point of infestation (Mill 1991; Costa-Leonardo 2002; Vasconcellos \& Bandeira 2006).

Existing methods to reduce damage in urban areas are based on backfill barriers of potent residual insecticides as well as chemical wood treatment (Su \& Scheffrahn 1998). Alternative methods based on baits impregnated with small amounts of insecticide are preferred to reduce the risk of accidental poisoning and environmental contamination (Su \& Scheffrahn 1993; Su \& Scheffrahn 1998; Rojas \& Morales-Ramos 2001). These have been used successfully in the control of subterranean termites of the genera Coptotermes and Reticulitermes, but have so far been ineffective with Nasutitermes termites (Su 1994; Costa-Leonardo 2002). Originally, N. corniger was assumed not to discriminate between the wood of different plant species (Bustamante 1998). However, Gazal et al. (2010) showed that Eucalyptus grandis was more heavily attacked than Pinus elliottii and Manilkara huberi wood, when offered simultaneously. Another factor that could influence the choice of $N$. corniger is the degree of wood decomposition. A positive effect of wood decay on attractiveness has been demonstrated in other termite species (Lenz et al. 1980; Lenz et al. 1991; Bustamante 1998).

This study aimed to investigate the attractiveness of wood altered by decomposition processes to $N$. corniger, with the intention of developing more suitable baits.

\section{MATERIAL AND METHODS}

\section{Maintenance of Termites in the Laboratory}

Twenty mature colonies of $N$. corniger (with alates termites present) were collected from trees located in different non-urban areas. The colonies were established in glass containers $50 \times 40 \times 60 \mathrm{~cm}$ and maintained under laboratory conditions of $25 \pm 5^{\circ} \mathrm{C}, 85 \pm 5 \%$ relative humidity (R.H.) and 10:14 h light:dark cycle (Gazal et al. 2010). Each colony was connected by a silicone tube $(8 \mathrm{~mm}$ in diameter) to an exclusive foraging arena consisting of a $50 \times 50$ $\mathrm{cm}$ glass plate with a $5 \mathrm{~cm}$ high perimeter wall. To avoid pre-conditioning to the wood types used in the experiments, prior to the experiments the termites were fed with cedar wood, Cedrela odorata L. (Meliaceae) and Hymenolobium elatum Ducke (Fabaceae). 


\section{Wood}

In the experiments, wood from the following trees was used: pine, Pinus elliottii Engelm. (Pinaceae); eucalypt, Eucalyptus grandis Hill (ex Maiden) (Myrtaceae); and massaranduba, Manilkara huberi Ducke (ex Chevalier) (Sapotaceae). These woods have very different densities (0.55, 0.81 and 1.10 $\mathrm{g} / \mathrm{cm}^{3}$, respectively) and geographic origin: Pinus elliottii originated from the United States, where it is considered a forest species of great importance (Drescher et al. 2001); E. grandis is native to the east coast of Australia; and M. huberi originated from Brazil's Amazon region (Azevedo et al. 2007).

The wood densities were calculated after determining the dry mass of a piece of freshly fallen wood of known volume. The three wood species were cut into pieces of $5 \times 2 \times 2 \mathrm{~cm}$ and a part of these wood was stored in a room at $15 \pm 5^{\circ} \mathrm{C}$ and $50 \pm 5 \% \mathrm{R}$.H. for a duration of 9 months to prevent decomposition (undecayed wood or control). The other part of the wood was exposed to weathering for 3, 6 or 9 months (decayed wood), respectively. The wood was exposed to weather as a monolayer on the terrace of the laboratory. The 9-month decay period began in June 2006, the 6-month period in September and the 3-month period in December of the same year, so they ended on the same date in March 2007 when the tests began. Rainfall, temperature, relative humidity and radiation data were recorded.

\section{Bioassays}

The bioassays were carried out separately for each of the three wood species. All the tests were carried out between 1:00 and 6:00 PM since a preliminary test in laboratory conditions demonstrated that $N$. corniger does not have a daily activity rhythm. Before beginning the tests, the linking tube from the nest to the foraging arena was obstructed with mineral cotton for 15 minutes to prevent the entrance of insects into the arena. Immediately, the maintenance food was removed and the termites within it were transferred to the nest. Then, the treatments (decayed pieces of wood of the same species by 3,6 and 9 months) and the control (one undecayed piece of wood) were placed in the arena on separate glass plates of $5 \times 2.5 \mathrm{~cm}, 10 \mathrm{~cm}$ apart from each other, equidistant $(20 \mathrm{~cm})$ from the point of access. For each test, the position of the treatment and control wood in the arena was randomized. The tests began when the access of the termites to the arena was reopened. Each experiment was carried out on twenty colonies of termites $(n=20)$. 
The tests started when the first termite contacted one of the wood samples. We then recorded the occurrence of: a) initial exploration, b) initial recruitment and c) massive recruitment behavior.

Initial exploration was considered to be when the first soldier made contact with a piece of wood, pressed its abdomen against it and then returned to the nest. Initial recruitment was considered to be when the first workers arrived at the wood source. Massive recruitment was considered to be when a large number of workers arrived at the wood source via a trail (Gazal et al. 2010).

After $1 \mathrm{~h}$ of observation, the plates containing wood and the termites present on them were removed and the termites present on each plate were counted.

The proportions in which the behaviors initial exploration, initial recruitment and mass recruitment occurred in the tests were compared between the decayed wood treatments and the undecayed wood (control) with Chi-square tests. The number of termites recruited at the end of the tests was compared by ANOVA and the means compared by Tukey's test $(\mathrm{p}<0.05)$. Due to the lack of normal distribution these data were log-transformed (Ln).

\section{RESULTS}

The climatic conditions to which the wood types were exposed are presented in Table 1. Only one of the climatic variables differed between treatments. Solar radiation was highest in the 3-month treatment (Kruskal-Wallis, $\mathrm{H}_{1}$, $\left.{ }_{350}=11.97, P<0.001\right)$. This treatment was performed in the summer months only, when radiation is invariably higher. The mean of other variables (rainfall, relative humidity and temperature) did not differ significantly between treatments (Kruskal-Wallis test). Therefore, the time of exposure to weather was assumed to be the main factor causing differences between the treatments.

The first contact of the termites with one of the wood pieces generally occurred a few minutes after opening the access to the arena. Initial exploration, initial recruitment and mass recruitment were observed to undecayed wood as well as to decayed wood, regardless of the treatment and species wood type (Table 2).

The proportion of initial exploration and initial recruitment did not differ between undecayed and decayed wood. However, the proportion of 
Table 1. Mean daily rainfall (frequency and volume), temperatures (minimum and maximum), relative humidity and solar radiation during weather exposure of wood decomposition treatments (3, 6 and 9 months).

\begin{tabular}{lcccccc}
\hline \hline $\begin{array}{l}\text { Treatment } \\
\text { (months) }\end{array}$ & \multicolumn{2}{c}{ Rainfall } & \multicolumn{2}{c}{ Temperature } & Relative & Solar \\
& $\begin{array}{c}\text { Frequency } \\
(\mathrm{n})\end{array}$ & $\begin{array}{c}\text { Volume } \\
(\mathrm{mm})\end{array}$ & $\begin{array}{c}\mathrm{min} . \\
\left({ }^{\circ} \mathrm{C}\right)\end{array}$ & $\begin{array}{c}\text { max. } \\
\left({ }^{\circ} \mathrm{C}\right)\end{array}$ & $\begin{array}{c}\text { humidity } \\
(\%)\end{array}$ & $\begin{array}{c}\text { radiation } \\
\left(\mathrm{Wm}^{-2}\right)\end{array}$ \\
\hline 0 (control) & $0.0 \pm 0.0$ & 0.0 & $10.0 \pm 0.3$ & $20.0 \pm 0.2$ & $50.0 \pm 5.0$ & 0.0 \\
3 & $0.5 \pm 0.1$ & $6.3 \pm 1.5$ & $21.4 \pm 0.1$ & $30.2 \pm 0.3$ & $84.0 \pm 0.7$ & $237.0 \pm 8.0$ \\
6 & $0.5 \pm 0.1$ & $5.2 \pm 1.0$ & $20.2 \pm 0.2$ & $28.6 \pm 0.3$ & $83.0 \pm 0.6$ & $218.0 \pm 6.0$ \\
9 & $0.4 \pm 0.1$ & $3.8 \pm 0.6$ & $19.0 \pm 0.2$ & $28.3 \pm 0.2$ & $81.2 \pm 0.5$ & $204.4 \pm 4.7$ \\
\hline
\end{tabular}

*significant difference in Kruskal-Wallis tests, $P<0.01$.

Table 2. Percentage of tests with occurrence of the three phases of foraging behavior (exploration, initial recruitment and massive recruitment) of Nasutitermes corniger on wood exposed to ambient conditions for 0 (control), 3, 6 and 9 months (treatments). The tests were replicated five times on four termite colonies $(n=20)$. Experiments were performed separately with wood of Pinus elliottii, Eucalyptus grandis and Manilkara huberi.

\begin{tabular}{lllll}
\hline \hline $\begin{array}{l}\text { Wood } \\
\text { species }\end{array}$ & $\begin{array}{l}\text { Treatment } \\
\text { (months) }\end{array}$ & $\begin{array}{l}\text { Behavioral event } \\
\text { Initial exploration } \\
(\%)\end{array}$ & $\begin{array}{l}\text { Initial recruitment } \\
(\%)\end{array}$ & $\begin{array}{l}\text { Massive recruitment } \\
(\%)\end{array}$ \\
\hline \multirow{5}{*}{ P. elliottii } & 0 (control) & 95 & 80 & 10 \\
& 3 & 90 & 65 & $30^{\text {ns }}$ \\
& 6 & 85 & 85 & $60^{*}$ \\
& 9 & 90 & 75 & $40^{\text {ns }}$ \\
& 0 & 95 & 80 & 15 \\
E. grandis & 3 & 90 & 75 & $25^{\text {ns }}$ \\
& 6 & 95 & 90 & $65^{*}$ \\
& 9 & 95 & 70 & $45^{\text {ns }}$ \\
& 0 & 80 & 65 & 10 \\
M. huberi & 3 & 85 & 65 & $20^{\text {ns }}$ \\
& 6 & 80 & 75 & $30^{\text {ns }}$ \\
& 9 & 95 & 80 & $50^{*}$ \\
\hline
\end{tabular}

*significant difference from the control in $\chi^{2}$ tests, $P<0.05$.

massive recruitment of termites to decayed wood was always greater than to undecayed wood.

In the tests with $P$. elliottii, recruitment was highest to wood exposed to weather for 6 months $\left(12 / 20\right.$ vs $2 / 20$ to undecayed wood, $\chi^{2}=8.90, P<$ $0.01)$. A similar result was observed in tests with $E$. grandis $(13 / 20$ vs $3 / 20$ 


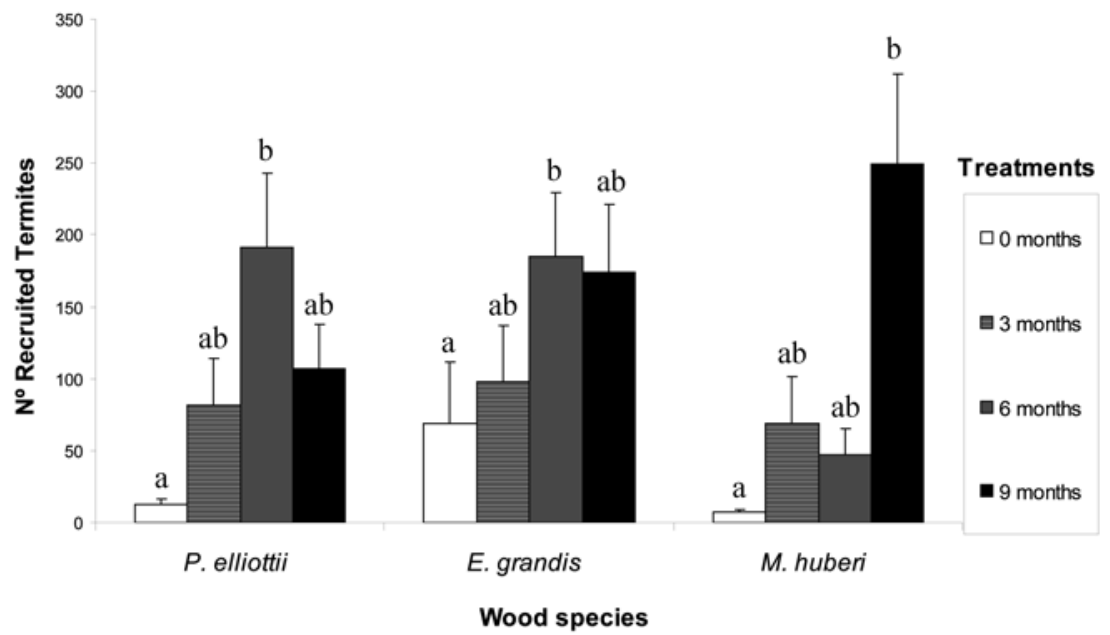

Figure 1. Number of Nasutitermes corniger termites recruited [Ln] (mean $\pm \mathrm{SE}$ ) after $60 \mathrm{~min}$ to undecayed and decayed wood (3,6 and 9 months) in a foraging choice arena. Separate experiments were conducted with the wood of Pinus elliottii, Eucalyptus grandis and Manilkara huberi. Different letters indicate significant differences between wood treatments in Tukey tests, $P<0.05$.

undecayed wood, $\left.\chi^{2}=8.44, P<0.01\right)$. The total number of termites recruited to decayed wood ( 6 months) at the end of the tests was also higher than to undecayed wood, both for P. elliottii (191.4 \pm 51.9 vs $12.4 \pm 4.1, \mathrm{~F}_{3,76}=3.44$, $P<0.05)$ and for $E$. grandis $\left(185.2 \pm 44.6\right.$ vs $69.0 \pm 42.8, \mathrm{~F}_{3,76}=3.82, P<$ $0.05)$. This behavior was similar among the different replications $\left(\mathrm{F}_{19,220}=\right.$ $0.97, P=0.41$ ).

In tests with $M$. huberi mass recruitment happened more times on decayed wood than on undecayed wood $\left(10 / 20\right.$ tests vs $2 / 20$ tests, $\chi^{2}=5.83, P$ $<0.05$ ), but in this case to the wood exposed to weather for 9 months (Table 2). Similarly, more termites were also recruited to decayed wood exposed for 9 months than to undecayed wood $\left(249.4 \pm 62.9\right.$ vs $7.3 \pm 2.1, \mathrm{~F}_{3,76}=2.91, P$ $<0.05$, Fig. 1).

\section{DISCUSSION}

Attacks by $N$. corniger to the undecayed wood of Pinus elliottii, Eucalyptus grandis and Manilkara huberi were recently described by Gazal et al. (2010). Given that the termites attacked the undecayed wood of all three species, even in situations in which decayed wood was also available, decay may not be a 
prerequisite for termite attacks (Esenther et al. 1961). On the other hand, the occurrence of mass recruitment to decayed wood of the three species indicates that the decay process was not restrictive to exploitation of wood as a resource. In our experiments, pine and eucalypt wood decayed for 6 months and massaranduba wood decayed for 9 months recruited more termites than the undecayed wood. Increase attractiveness of decomposed wood to termites may be a consequence of changes in nutritional value due to the action of fungi. The wood decomposition process can release toxic compounds, but can also increase nutrient availability (Waller \& La Fage 1987). Further, changes in the physical structure caused by depolymerization of cellulose, including cell wall thinning, bore hole formation and rounded pit erosion, may ease fiber removal (Erwin et al. 2008). In addition, allelochemicals that influence the foraging behavior of termites may also be released (Cornelius $e t$ al.2002), some of which, for example, may trigger trail following (Esenther \& Beal 1979; Rust et al. 1996). Extracts from decayed wood have been used to direct subterranean termite foraging toward a bait station ( $\mathrm{Su} 2005$ ).

In this study, P. elliottii and E. grandis wood was most attractive to termites after a decay period of 6 months, but $M$. huberi wood was most appealing after a decay period of 9 months. This difference may be due to lower rates of water retention of dense wood resulting in slower decomposition (Bultman \& Southwell 1976). Wood with higher density, such as M. huberi, may need to be exposed to the weather for longer to undergo chemical or physical changes equivalent to that occurring in eucalypt or pine wood.

Contrary to expectation, E. grandis and P. elliottii decayed for 9 months were not preferred to undecayed wood. This indicates a drop in attractiveness at a certain point in the decomposition process. A similar response was found in studies with the termites Coptotermesformosanus Shirak and Reticulitermes flavipes Kollar, when wood decayed for 8 weeks was preferred to the undecayed wood, but wood decayed for 12 weeks was not (Cornelius et al. 2003). Perhaps the ease of fiber removal or gains in nutritional quality in the short term do not compensate indefinitely for nutrient losses associated with the decomposition process longer. Alternatively, increased attractiveness may be offset by the simultaneous production of toxic or repellent chemicals.

Wood is often used as a bait substrate to facilitate the distribution of insecticide within termite colonies. In this study, we found that undecayed 
and decayed wood offered together are attractive food sources for N. corniger. However, differences in the mass recruitment of foragers suggested that this termite species is more attracted to decayed wood. Therefore, it may be beneficial to use decayed wood when preparing insecticide-impregnated baits for $N$. corniger termites.

Future research is needed to determine whether increased recruitment to decayed wood is a result of physical or chemical changes in the wood, and also to investigate the role of different decomposing agents in this process.

\section{ACKNOWLEDGEMENTS}

We are indebted to Veronica Figueiredo, Pamella Rosa and Arli de Fatima, for helping in the laboratory. V.S.S. Gazal was financially supported by CAPES.

\section{REFERENCES}

Azevedo, V.C.R., C.C. Vinson, V.P.Silva \& A.Y.Ciampi 2007. Desenvolvimento e Aplicação de Marcadores Microssatélites em Maçaranduba Manilkara huberi. Biotecnologia 1:5-19.

Bultman, J.D. \& C.R. Southwell 1976. Natural resistance of tropical woods to terrestrial wood-destroying organisms. Biotropica 8:71-95.

Bustamante, N.C.R. 1998. Nutritional attractiveness of wood-feeding termites inhabiting floodplain forest of the Amazon river, Brazil. Acta Amaz. 28:301-307.

Cornelius, M.L., D.J. Daigle, W.J. Connick Jr., A. Parker \& K. Wunch 2002. Responses of Coptotermes formosanus and Reticulitermesflavipes (Isoptera: Rhinotermitidae) to three types of wood rot fungi cultured on different substrates. Sociobiology 95:121-128.

Cornelius, M.L., D.J. Daigle, W.J. Connick Jr., K.S. Williams \& M.P. Lovisa 2003. Responses of the Formosan subterranean termite (Isoptera: Rhinotermitidae) to wood blocks inoculated with lignin-degrading fungi. Sociobiology 41:513-525.

Costa-Leonardo, A.M. 2002. Cupins-Praga: morfologia, biologia e controle. Divisa. 128. Rio Claro, São Paulo.

Drescher, R., P.R. Schneider, C.A.G. Finger \& F.L.C. Queiroz 2001. Artificial Form Factor of Pinus elliottii Engelm for the Region of "Serra do Sudeste", Rio Grande do Sul (BRAZIL). Ciencia Rural 31:23-35.

Erwin, S. Takemoto, W.J. Hwang, M. Takeuchi, T. Itoh \& Y. Imamura 2008. Anatomical characterization of decayed wood in standing light red meranti and identification of the fungi isolated from the decayed area. J. Wood Sci. 54(3):233-241.

Esenther, G.R. \& R.H. Beal 1979. Termite control: decayed wood bait. Sociobiology $4: 215-222$. 
Esenther, G.R., T.C. Allen, J.E. Casida \& R.D. Shenefelt, 1961. Termite attractant from fungus infected wood. Science 1:43-50.

Gazal, V., O. Bailez, A.M. Viana-Bailez 2010. Wood preference of Nasutitermes corniger (Isoptera: Termitidae) (Motschulsky). Sociobiology 54:1-11.

Lenz, M., D.B.A. Ruyooka, C.D. Howick 1980. The effect of brown and white rot fungi on wood consumption and survival of Coptotermes lacteus (Froggatt) (Isoptera: Rhinotermitidae) in a laboratory setting. Zeitschriftfuer Angewandte. Entomologie 89:344-362.

Lenz, M., T.L. Amburgey, D. Zi-Rong, J.K. Mauldin, A.F. Preston, D. Rudolph \& E.R. Williams 1991. Inter-laboratory studies on termite-wood decay fungi associations: II. Response of termites to Gloeophyllum trabeum grown on different species of wood (Isoptera: Mastotermitidae, Termopsidae, Rhinotermitidae, Termitidae). Sociobiology 18:203-254.

Mill, A.E. 1991. Termites as structural pest in Amazonia, Brazil. Sociobiology 19:339348.

Rojas, M.G. \& J.A. Morales-Ramos 2001. Bait matrix delivery of chitin synthesis inhibitors to the formosan subterranean termite (Isoptera: Rhinotermitidae). J. Econ. Entomol. 2:506-510.

Rust, M.K., K. Haagsma \& J. Nyugen 1996. Enhancing foraging of western subterranean termites (Isoptera: Rhinotermitidae) in arid environments. Sociobiology 28:275286.

$\mathrm{Su}$, N.Y. 1994. Field evaluation of hexaflumuron bait for population suppression of subterranean termites (Isoptera: Rhinotermitidae). J. Econ. Entomol. 87:389-397.

$\mathrm{Su}$, N.Y. 2005. Directional change in tunneling of subterranean termites (Isoptera: Rhinotermitidae) in response to decayed wood attractants. J. Econ. Entomol. 2:471475.

Su, N.Y. \& R.H. Scheffrahn 1993. Laboratory evaluation of two chitin synthesis inhibitors, hexaflumuron and diflubenzuron, as bait toxicants against the Formosan subterranean termite (Isoptera: Rhinotermitidae). J. Econ. Entomol. 86:1453-1457.

Su, N.Y. \& R.H. Scheffrahn, 1998. A review of subterranean termite control practices and prospects for integrated pest management programs. Int. Pest Manage. Review 3:113.

Vasconcellos, A. \& A.G. Bandeira 2006. Populational and Reproductive Status of a Polycalic Colony of Nasutitermes corniger (Isoptera, Termitidae) in the Urban Area of João Pessoa, NE Brazil. Sociobiology 1:165-174.

Waller, D.A. \& J.P. La Fage 1987. Nutritional ecology of termites. In: Nutritional ecology of insects, mites, and spiders. Eds. Slansky F, Rodriguez JG, Wiley, New York, NY, 487-532. 
